A COMMENTARY ON THE POSITIVE DISCRIMINATION POLICY OF INDIA

ISSN 1727-3781

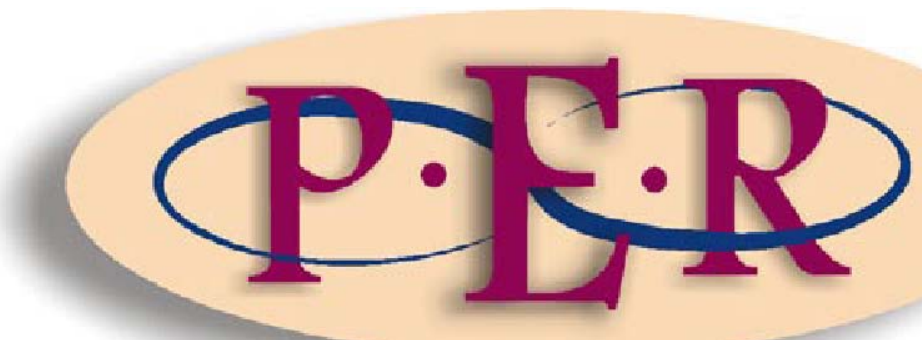

2009 VOLUME 12 NO 1 


\section{A COMMENTARY ON THE POSITIVE DISCRIMINATION POLICY OF INDIA}

T Deane*

\section{Introduction}

Affirmative action ${ }^{1}$ and discriminatory measures are complex and controversial issues. The purpose of affirmative action is to speed up the establishment of a representative and unprejudiced workforce in addition to assist those who were in the past deprived by unfair discrimination to fulfil their highest potential. ${ }^{2}$ The term itself invokes emotions that range from fear and rage to satisfaction. ${ }^{3}$ Affirmative action has encouraged an ongoing debate regarding the legal, moral and economic questions arising from the preferential treatment of certain groups of people in society. ${ }^{4}$ Underlying this debate are various concerns about the notion of reverse discrimination or unfairly disadvantaging individuals who bear no responsibility for past or present discrimination practised by others.

This article states the current position with regard to the caste system of and the reservation of jobs in the Republic of India in the context of affirmative action and the achievement of equality in the workplace. Its purpose is to highlight the extreme division of opinion about what is socially acceptable, namely, caste. Further, it provides the reader with an understanding of the need for affirmative action in the first place in India and thereby creates a powerful tool for understanding discrimination and the need for affirmative action measures. Another goal is to provide useful guidelines and information to all persons involved in implementing affirmative action programmes. It serves to

* Dr Tameshnie Deane. Senior Lecturer, Criminal and Procedural Law, University of South Africa.

1 The term "affirmative action" has different meanings and definitions which flow, and are derived from an individual's view of the legitimacy of the use of race-conscious or sexconscious preferential remedies for unlawful discrimination. Alternative terminology used to define or describe affirmative action includes but is not limited to "reverse discrimination", "affirmative discrimination" or "quotas" as in the Indian context.

2 White Paper GN 564 in GG 18800 of 23 April 1998.

3 Turner Past and Future 1.

4 Hodges We Want Jobs. 
show that if affirmative action measures and/or discriminatory measures are not properly thought out then affirmative action becomes burdensome and even more discriminatory rather than a means of achieving equality and redressing past wrongs.

One might ask what benefit this analysis of the aspects of the Indian constitution dealing with affirmative action policies has for the South African context. An analysis of the political, legal and constitutional systems of other countries is very relevant. It helps to promote a better understanding of a country's own situation and assists in a proper evaluation of one's own institutions. It also assists in the interpretation of constitutions and help to enforce human rights. ${ }^{5}$ Further, whenever there is a controversial topic like affirmative action, which poses a great deal of difficulty, such a problem can be solved with the help of a comparative study. ${ }^{6}$ This study will also be useful in that the experiences in India may be helpful in informing South Africa of the future and long-term consequences of affirmative action. Therefore this study of the relevant constitutional provisions relating to equal opportunity in this country becomes important. This approach becomes useful in that experiences in one country will help enrich another country to learn from such practices.

However, it must be cautioned that when a country is looking at the experiences of other countries, the specific history of its own country must be born in mind together with the remedies and aims that its constitution wants to achieve. Therefore, even though South Africa will do well to look beyond its own borders when implementing affirmative action programmes it should do so with circumspection, taking into account its own specific history.

5 This information originally appeared in Ginsburg 2000 Brookings Review 3, and is drawn from the Cardozo Lecture given by Justice Ginsburg at the Association of the Bar of the City of New York on 11 February 1999.

6 Bhandari Basic Structure 110. 


\section{Beginnings of discrimination in India - the Caste System}

There are many other countries and nations that are characterised by inequalities including social inequalities but in India these inequalities are highly structured in the form of caste. Caste has existed in India for such a long time and has undergone considerable change but it still involves millions of people. The continuation of superiority and inferiority by reason of ones skin colour, religion and economic and social status is a world-wide phenomenon. The caste system was not the creation of a single person like the raja (king). To a certain extent it developed out of a system of social practice that became a norm or way of life over several thousands of years.

The issue of caste is a very complex and complicated one. Caste is perceived as "an exclusively Indian phenomenon which is not paralleled by any other institution elsewhere in its complexity, elaboration and inflexibility". 7 Kroeber describes the caste system as a "system of social stratification, examples of ranked aggregates of people, that are usually rigid, birth-ascribed, and permits no individual mobility". ${ }^{8}$ In the caste system everyone is classified. The castes, like the system of apartheid and racial discrimination, teach us a fundamental social principle; hierarchy. ${ }^{9}$ This classificatory system assumes that certain traits, qualities, functions, characteristics or powers are inherent in and definitive of each of the varnas. This system of caste is enormously complicated and not easily understood. The following paragraph attempts to simplify the issue of caste so as to give the reader an understanding of how the system works.

There are many and varied theories about the establishment of the caste system. These include religious, biological and historical theories. ${ }^{10}$ According

7 Searle-Chatterjee and Sharma Contextualising Caste.

8 Kroeber "Caste".

9 Ghurye Features of the Caste System.

10 The biological theory of the caste system claims that all existing things have essentially three qualities in different ratios. Sattva qualities include wisdom, intelligence, honesty, goodness and other positive qualities. Rajas include qualities like passion, pride, valour and other passionate qualities. Tamas qualities include dullness, stupidity, lack of creativity and other negative qualities. People with different doses of these inherent qualities 
to the caste system a person is regarded as a part or member of the caste into which he or she is born. Such person therefore remains within that caste until their death, although the exact standing of that caste may vary among the regions of India and over time. Thus, caste is a many-layered social hierarchy developed several millenniums ago. In Hindu custom the caste system owes its origins to the four varnas. ${ }^{11}$ One of the religious theories gives details on how the four varnas were founded. ${ }^{12}$

Accordingly, there are five different levels or categories of this system. They are the Brahman, Kshatriya, Vaishya, Shudra, and Harijans ranked in accordance of hierarchy. Within each of these categories are the actual "castes" or jatis. It is within these ranked categories that people are born, in which they marry, and in which they die. This system has worked well for Indian people in segregating them and even now plays a fundamental role in contemporary India. It therefore becomes interesting to see how positive discrimination has affected the caste system and its people therein.

It has been argued that in the general sense, some societies are actually or were caste-based in nature and these include countries like South Africa during the era of apartheid and the South of the United States of America until the Civil Rights movement. Nevertheless, differentiations arise when comparing caste-like systems in other nations to India. In other countries, like South Africa and the United States of America, the separation between one group and the other was typically along ethnic or racial lines. ${ }^{13}$ In India, the separation was more indistinct as one caste in India would appear very much like another. Like race, caste is something one is born into. However, caste in India is more of a social structure, in contrast to the situation in the US, where "race is a fixed and obvious physical condition". ${ }^{14}$

adopted different types of occupation. It was this difference in qualities and occupation that was the origins of the caste system. See for instance Buhler "Manu".

11 Buhler "The Sacred Laws of the Aryans".

12 Doniger Laws of Manu.

13 Sachs "Affirmative Action".

14 Volokh 1996 volokh.com/sasha/quotas.html. 
Another theory relating to the beginnings or origins of caste has to do with the time that India was colonised by the British. India was once a British colony. The British left behind them in India a legacy of their ideologies and culture and even today it is evident that English, the language of their oppressors, is a very important and respected language in India. The British influence is apparent even in most of the laws in India. Some laws, as in South Africa, have been directly adopted and adapted from the English laws.

Some researchers propose that the resultant representation of the caste system was to a great extent the product of European racialist theories, and the benefit of colonial rule as a phenomenon grounded in Indian cultural realities. Contemporary researchers further propose that preceding the colonial period castes were much more open and flexible. This proposition is supported by various passages in the Vedas which indicate that the four varnas were originally based on occupations and not simply decided by one's birth. It was at a later stage that the present inflexible caste system came into place.

However, with regard to the caste system, the first effect of importance that the British had on the caste system was to reinforce it. It has been argued that the British saw the advantages in preferring some groups to others. As the Brahmins were once very powerful in influencing the people of India, they gave returned to the Brahmans special privileges that the previous Muslim rulers had taken away.

Even though privileges were given to certain of the groups in India, for the most part the discriminatory practices that were practised amongst the various groups were completely ignored by the British. Some have argued that this attitude was seen as a form of indirect support for the caste system by the British. The overall British policy towards caste was seen as a policy of noninterference. $^{15}$ 
While researchers hold opposing views on the origins of the caste system in India, they hold the same opinion that it is a very ancient institution that has led to vast inequalities in Indian society. The extreme manifestation of such inequalities in India led to a growing awareness of the need for reform. ${ }^{16}$ Affirmative action was needed to outweigh the imbalances of the past. In India, affirmative action is known as "preferential treatment", "protective discrimination" or "reverse discrimination". It is known by the name of reverse discrimination because it involves discrimination in favour of those who, until recently, had themselves been the victims of discrimination. ${ }^{17}$ The phrase "reverse discrimination" may mean different things to different people. The phrase is sometimes charged with being a term of prejudice and is restricted to refer to those situations where an absolute preference is given to the preferred groups. ${ }^{18}$ In India the term most commonly used is positive discrimination. ${ }^{19}$

In the preamble to the Constitution of India, negative public discrimination on the basis of caste is forbidden. However, ranking according to one's caste and caste-based interaction have transpired for centuries and it seems that they will carry on doing so well into the predictable future. As stated earlier, caste systems in India and caste-like groups are ranked. Within most communities or townships (villages), the relative rankings of each locally represented caste is known, and people's attitudes toward one another are continuously fashioned by this knowledge. The caste system is seen as a closed assembly whose members are strictly confined in their choice of employment and the amount of social involvement. One's status in society is decided by the caste of one's birth and may hardly ever be transcended. A specialised labour group may function as a caste inside a society otherwise free of such distinctions. ${ }^{20}$ In general, caste serves to uphold the status quo in the Indian social order.

16 Anand Equality 1.

17 Fischer 1996 People Dynamics 32.

18 Brounaugh "Authority, Equality, Adjudication, Privacy" 47.

19 Andrews 1992 SAIPA 34-43.

$20 \mathrm{Eg}$, the ironsmiths in parts of Africa. 
It is because of this hierarchal construction, with its rising order of opportunities and its sliding order of disabilities, which has been in operation for about 3000 years, that there was and continues to be an overwhelming majority in the nation that are socially, economically, educationally, and politically backward. These victims of entrenched backwardness comprise the present Scheduled Castes (SCs), Scheduled Tribes (STs) and Other Backward Classes (OBCs). These classes are generically called the "backward classes", but each class's nature and magnitude of backwardness are not the same. ${ }^{21}$

\section{Reservations}

The Indian government has a policy of compulsory compensatory discrimination which comprises various preferential schemes. The policy initiative most commonly utilised by them to offset the inequalities of society is a policy of reservations. ${ }^{22}$

Reservations are a type of affirmative action whereby a proportion of seats are set aside for the previously disadvantaged. Reservations take place in the "Parliament of India, state legislative assemblies, central and state civil services, public sector units, central and state government departments and all public and private educational institutions". According to the Indian Constitution the exception lies in the minority and religious educational institutions for the socially and educationally backward classes of citizens or the Scheduled Castes and Scheduled Tribes, who are perceived by the government to be inadequately represented in these services and institutions. ${ }^{23}$ Therefore the term "reservations" indicates a set allocation of certain public service positions for recognised minorities. This term encompasses the allocation of seats in educational institutions as well. ${ }^{24}$

21 Sharma and Reddy Reservation Policy in India.

22 Tummala 1999 Public Administration Review 495-508.

23 Sukhnandan Thakur v State of Bihar (1957) AIR 617 (Pat).

24 Although such reservations were declared unconstitutional in various decisions. Surendra Kumar v State (1969) AIR 182 (Raj); Ramachandra v State of Madhya Pradesh (1961) AIR 247 (Madh Pra). 
The stated reason for the implementation of reservation is the necessity to advance the needs and interests of any socially and educationally backward classes of citizens, such as the scheduled castes and scheduled tribes, who had been subjected to discrimination for more than thousands of years by the upper caste men of India. ${ }^{25}$

Preferences in India are of three basic types. Firstly, there are reservations. These reservations assign or make possible access to esteemed positions or resources. ${ }^{26}$ Secondly, there are programmes involving expenditure or the provision of services for e.g. scholarships, grants, loans, land allotments, health care, and legal aid to the beneficiary groups. ${ }^{27}$ Thirdly, there are special protections. ${ }^{28}$ Reservations together with other welfare initiatives comprise the heart of affirmative action for these previously disadvantaged groups. ${ }^{29}$ To indicate the scale of this policy the central government has set aside twentyseven percent of all government jobs and places in institutions of higher education for the socially and educationally backward classes. ${ }^{30}$

Specifically, the Constitution of India provides for "reservations" in favour of two disadvantaged groups; namely, the Scheduled Castes (SCS) and the Scheduled Tribes (STs). These reservations exist in the following areas:

(a) in the state legislatures and the union legislature or parliament,

(b) in services under the states, and

25 Constitution of India 1950 (hereafter IC).

26 The most important instances of this type are reserved seats in legislatures, the reservation of posts in government service, and the reservation of places in academic institutions.

27 Galanter Competing Inequalities 42-43.

28 These distributive schemes are accompanied by efforts to protect the backward classes from being exploited and victimised.

29 This policy consists of various schemes allowing preferential treatment, a reservation of a percentage of government jobs and of places in educational institutions being the most important.

30 The IC provided the legal opportunity for preferential treatment for their benefit even before it was clear who the Socially and Educationally Backward Classes were. The makers of the IC left the work of defining, selecting, and listing the backward classes to special commissions in the States and in the Centre. 
(c) in educational institutions.

Apart from reservations in educational institutions, other programmes for the upliftment of the backward classes include:

(a) exemption from school fees,

(b) the provision of stipends or scholarships,

(c) the provision of facilities like book grants, and

(d) the maintenance of hostels, or assistance to hostels for SC students. $^{31}$

The central government further sponsors the following:

(a) college scholarships,

(b) the award of travel grants, and

(c) a seven-and-a-half percent reservation in favour of SCs in merit scholarships,

(d) assistance by way of special coaching for the SC students residing in hostels, and pre-examination coaching facilities for SC students appearing in competitive examinations, ${ }^{32}$ and

(e) in some states, reservations in services under the state and in educational institutions in favour of OBCs. Reservations coupled with other welfare programmes constitute the core of affirmative action for the upliftment of these groups. ${ }^{33}$

In Parliament and in state legislatures political reservation is only for the benefit of the SCs and the STs but not for the other OBCs. Political reservations are written into the Indian Constitution and the provisions make known the uncertainty of the architects of the Constitution as well as of policy makers in modern day India. ${ }^{34}$

31 Seenarine "Dalit Women".

32 Ibid.

33 Ibid.

34 Galanter (n 27). 
The constitutional provisions relating to political reservations for the SCs and the STs are compulsory. However, when the provisions were made obligatory in 1950, it was determined that this would be valid only for ten years, so they would last for a single decade only. However, since then the Indian Constitution has had to be amended every ten years to continuously extend political reservations for the SCs and STs.

The second category of reservation, which is even more controversial than the first, is identified as job reservations. ${ }^{35}$ Job reservations pertain mainly to government appointments at union and state level and also to organisations which are significantly subsidised by the government. The provisions for job reservation apply not only to the SCs and STs but also to the OBCs as well. It has happened that over the years there has been an extension of job reservations for the benefit of the OBCs. This has now become the most controversial issue among positive or affirmative action measures in India. The question is whether or not the wholesale expansion of job reservations for the $\mathrm{OBCs}$ is in harmony with the will of the Constitution or not. For job reservations, unlike political reservations, the provisions are not obligatory; they are enabling provisions since the Indian Constitution states that the state may take such measures as are necessary for the special benefit of the OBCs.

Finally, the third category of reservation is reservations in education. As far as admissions are concerned, it is possible that the different States of India may grant concessions short of outright reservation to handicapped persons, for e.g., the awarding of stipends and scholarships etc. As there is no legislation mandating the equal and fair representation of disabled persons in the workforce. these concessions may prove to be inadequate. ${ }^{36}$ These, again, are debatable, because reservations are present not only in general arts and science courses but also in medical and engineering schools. The reasoning 
behind reservations in India is that special opportunities should be given for some, over and above the general provisions for equality of opportunity for all.

The key aim for providing reservations for SCs and STs in civil posts and the services of the Government is to provide jobs to some persons belonging to these communities and thereby increase their representation in the services; so as to facilitate their social and economic advancement and make due place for them in society. Article 16(4) of the Constitution specifically empowers the State to make any provision for the reservation of appointments or posts in favour of any backward class of citizens which is not adequately represented in the services under the State. With the same end in view, the Constitution envisaged in the Directive Principles of State Policy and elsewhere the economic and educational development of the weaker sections, particularly the SCs and STs.

\section{$4 \quad$ Quotas}

Countries looking to implement affirmative action policies will do well to look at India's affirmative action policies, as India is the country with the most extensive quota system in the world, and it is a country where the government enforces these preferences. Quotas are enforced through this system of reservations, whereby at least forty percent of seats are reserved for persons from the SCs, STs and OBCs. Mitchell describes the quota system as a "numbers game enforced by a policing system supported by industrial courts" and warns that the quota methods can prove to be counter-productive with companies resorting to filling quotas without developing skills. ${ }^{37}$

Like the quota system in other constitutions ${ }^{38}$, seats and jobs are reserved for persons from disadvantaged groups. ${ }^{39}$ This policy of special or preferential 
treatment of the disadvantaged sections of society is called by the name of "protective discrimination" 40 or "protective measures", "compensatory discrimination programmes" ${ }^{41}$ or "reverse discrimination". ${ }^{42}$ These phrases however, have the same import and are not dissimilar to the concept of affirmative action as used in the South African and the US context. The difference is that whereas in the South African context affirmative action means more than just the achievement of numerical goals or targets, the Indian policy of affirmative action subscribes mainly to the policy of the reservations of jobs and the reservation of places for admissions at universities.

As can be seen, reservation policies in favour of the backward classes in India are quite extensive and form the major part of the preferential policies designed for their upliftment.

\section{$5 \quad$ Beneficiaries of affirmative action in India}

Like race, caste is something one is born into. ${ }^{43}$ However, because caste in India is a "social construction", in contrast to the beliefs in the US that "race is an obvious physical condition", it is believed that the "Indian jurisprudence has advanced well beyond American law in constructing and justifying affirmative action in terms of underlying social features". ${ }^{44}$

39 Reservations are being made in the services as well as both at the point of initial entry and in promotions. This benefit has been extended to embrace the whole chunk of weaker sections.

40 It is given the name "protective discrimination" because the purpose of special or preferential treatment is not to award any special privileges but to give protection to those who, because of centuries of oppression, are vulnerable to get exploited despite the removal of legal sanctions behind exploitation which has been practised so far.

41 These programmes are authorised by constitutional provisions that permit departure from formal equality for the purpose of favouring specified groups. See in this respect Galanter (n 27) 41and 379. Also see the case of Devadasen v Union of India (1964) AIR 179 (SC).

42 It is known by the name of "reverse discrimination" because it involves discrimination in favour of those until recently had themselves been the victims of discrimination.

43 Volokh (n 14).

44 Cunningham 1997 Mich LR. 
Attention has focussed on protective discrimination or preferential treatment for three major classes; the SCs, ${ }^{45}$ the $\mathrm{STs},{ }^{46}$ and more recently the OBCs. Included among the OBCs are a few tribal and nomadic groups, as well as converts to non-Hindu religions from the scheduled caste and in some areas the Denotified Tribes. ${ }^{47}$ The inclusion of the category of the OBCs widens the principle of affirmative action in education and government employment from the untouchables to "socially and educationally backward classes of citizens", 48 of assisting "backward" groups, "backwardness" or the "depressed classes" 49 , it should be understood as a comparison rather than a depreciatory or condescending phrase. ${ }^{50}$

Another group that receives preferential treatment in India is women and children. Under clause (3) of article 15 of the IC, special provision for the benefit of women and children may be made by the State and such special provision will not be open to attack as contravening articles 14 or $15^{51}$

The making of reservations as "compensatory discrimination" in India does not look to eradicate the caste system; it simply aims to boost some oppressed castes, whether at the bottom or the middle of the caste ranking. The Indian government's model of "affirmative action" is different in a way from that in other Constitutions ${ }^{52}$ as these other societies do not have any inflexible castebased pecking order of jati (the endogamy family) and varna (class based on purity level) as the Indians do, but only classes fashioned by economic

$45 \mathrm{Cl} 24$ of art 366 of the IC.

$46 \mathrm{Cl} 25$ of art 366 of the IC.

47 The Denotified Tribes, or Vimukta Jatis, are the former Criminal Tribes. They became 'excriminal' when the Criminal Tribes Act of 1924 was repealed in 1952.

48 Art 15(4) of the IC. What is interesting is that in India both traditional low-caste status and economic class are factors in determining whether a group is categorised as an OBCs, but these factors on their own are not considered to be sufficient.

49 The term backward classes is commonly used in two senses: (a) as a generic term including the Scheduled Castes and Scheduled Tribes as well as the other so-called Other Backward Classes; or (b) as a designation of those backward groups not included in either of the first two categories. See art 15(4) of the IC.

50 Cunningham (n 44) 119.

51 Savitri v KK Bose (1971) AIR 1974 (HP); Padmaraj Samendra v State (1979) AIR 266 (Pat).

52 Like the USA and South African Constitutions. 
inequality. In such a culture, the economic progression of an individual, family unit or group brings about a confirmed position in a privileged class.

However, in the Indian system, affluence alone has not improved the status of a caste (jati) into a higher varna. It is submitted that the reservation of government positions for OBCs should not be construed as a narrow exemption to the constitutional guarantee of equality, but rather as a way of achieving true, substantive equality, notwithstanding the concomitant problems. To combat the problems entailed in the identification of beneficiaries, the identification of a group as an $\mathrm{OBC}$ cannot and should not be based on economic criteria alone.

\section{Conclusion}

Like many other Constitutions and anti-discrimination legislations, the Constitution of India does not contemplate affirmative action/reservation and special treatment as a general principle of operation. With a view to making justice - social, economic and political justice- effectively available to all, the Constitution of India makes special provision for certain members of society. The IC contains several provisions for the protection and amelioration of the lot of the SCs, the STs and the OBCs.

The problem with the caste system is that the higher caste communities feel discriminated against by the government's policy of reserving positions for the OBCs. The situation exists where in many cases a large number of members belonging to the higher castes contend for the small number of places reserved for them, while the members of the backward classes do not have to compete at all because of the large number of reserved places for them compared with the small number of candidates. This reservation system in favour of the backward classes seems to be leading to a situation of unfair reverse discrimination. To have such a high percentage of reservations as well as other measures for the upliftment of the backward classes at the expense of the promotion of the upper caste of society seems to be in direct violation of 
various rights and would a minefield for unfair discrimination law in South Africa.

Another problem that one faces when debating the constitutionality of affirmative action measures relates to the "suitably qualified" individual. The fact that the Constitution of India specifically provides for affirmative action programmes in an elaborate manner has not lain to rest the controversies surrounding this issue. In fact the issue raises questions of great importance to legal theory and philosophy. One such problem relates to the merits of the affirmative action candidates. When looking at the Indian courts' approach to this issue, even though they have emphatically rejected the notion of appointing unsuitably qualified candidates to positions or admitting them to universities and colleges, they have endorsed this approach by providing for strict quotas and reservations. The problems relating to this issue then arise with the appointment of an affirmative action candidate on the basis of a quota system.

What this should mean for South Africa is that when one is choosing a suitably qualified person then the employer must take account of various relevant criteria. The employer is not obliged to employ someone merely to fill a quota. Affirmative action programmes ought to aspire to help the underprivileged sectors of society by allowing them to catch up with the standards of competition set up by society at large. However, it is submitted that numerical quotas or reservations are intolerable as they impose unfair burdens on those excluded and they involve the suspension of standards.

In India, quotas and job allocations or reservations have not brought equality, dignity, or even safety for India's untouchables. ${ }^{53}$ In South Africa, in order to make certain that affirmative action is constitutional, one has to reject the idea of strict numerical quotas. These reservations or quotas seem to be baseless and are there purely for political gain. Further, rather than leading India towards a "casteless" society, the policy of reservation and quotas seems to have reinforced caste identities. Affirmative action that opens up new opportunities 
and makes available the resources and the seats in employment and universities is the path that South Africa should follow. The question remains on how this is to be achieved. One of the ways in which this can be achieved is by ensuring the development of skills.

Even so, in the Indian situation there is definitely no question of discarding affirmative action programmes in favour of the socially disadvantaged persons as the designated beneficiaries are still very much disadvantaged. Looking at the history of injustice in South Africa, abandoning affirmative action programmes just at present will not lead to justice or equality. It is neither practical nor desirable to do so. It would seem that Equal Employment Opportunity programmes are consistent with and even required by the antidiscrimination principles. ${ }^{54}$ Affirmative action is part and parcel of a just society, so there should be no question of abandoning affirmative action programmes for the designated groups at present. However, these programmes must be carried out in a way that is constitutionally acceptable.

In India, the need really is to make these affirmative action programmes more effective, instead of confining them to reservations alone. Other programmes as contemplated by South Africa should be followed. For example, programmes for special training and the development of skills, and measures to encourage the previously disadvantaged to pursue excellence should be taken up. Reservations or quotas alone can never be the answer.

The Indian experience cautions one about the difficulties of assessing affirmative action programmes. Further, it has shown that compensatory discrimination does not necessarily extinguish commitments to merit. On the other hand, it does not automatically produce the sought-after redistribution and it is not costless, ${ }^{55}$ since, in India, in order to fill quotas, candidates from the lower classes are accepted even though they are not suitably qualified.

54 Ryan and Evans 1984 The Commonwealth Government Canberra 15-16.

55 Galanter (n 27) 563. 
Sometimes some positions that are reserved remain unfulfilled as there are too few candidates from the lower classes to fill them. This causes tension between the castes. There are tensions over reservations between the lower castes as well.

In the order of precedence for a place set aside for the OBCs, candidates from the SCs are preferred over candidates from the STs, who in turn are preferred over candidates from the other OBCs. According to central government policy, OBCs constitute about fifty percent of India's population, but only twenty percent of the OBCs are actually entitled to positive discrimination. Some OBC communities are organising politically to be recognised as backward classes entitled to positive discrimination. The STs, who are seen as the aborigines of India, have ownership and certain rights over the land. Many communities in India also claim to be aborigines of India, and they are claiming the same rights as the STs.

The term "Scheduled Castes" itself refers to a list of castes prepared in 1935 by the British government in India. ${ }^{56}$ Such a list is kept today, supplemented by lists of other STs and OBCs, and includes three thousand SCS, STs and OBCs. According to the central government policy these three categories are entitled to positive discrimination. Sometimes these three categories are defined together as "Backward Classes". It is these groups that benefit from positive discrimination. In accordance with constitutional provisions and various laws, the state grants dalits or the untouchables a certain number of privileges, including reservations (quotas) in education, government jobs and government bodies.

The implementation of legal provisions contained in the Protection of Civil Rights $\mathrm{Act}^{57}$ and the Scheduled Castes and Scheduled Tribes (Prevention of

56 See art 3441 and 342 of the IC. The government of India's 1960 publication entitled Scheduled Castes and Tribes Arranged in Alphabetical Order lists 405 SCs and 255 STs, for a total of 660 kinship groups (the boundaries distinguishing castes and tribes are unclear).

57 The Protection of Civil Rights Act of 1995. 
Atrocities) Act attempts to protect these castes from discrimination. ${ }^{58}$ The Constitution therefore permits the privileging of the SCs, STs and OBCs. It specifically provides reserved seats in the lower house of Parliament ${ }^{59}$ and in the lower houses of the state legislatures for the SCs and STs. ${ }^{60}$ The Constitution of India itself does not define these groups, nor does it provide detailed standards by which they may be determined. In the case of SCs and the STs, it does prescribe an agency and a method for designating them. ${ }^{61}$ Not only are the OBCs left undefined in the Constitution, but no such method or agency for their determination is provided. ${ }^{62}$

This list of beneficiaries in India is perhaps one of the largest lists in the world, as no other country provides for positive measures for such a large group of beneficiaries. Reservations are proposed to increase the societal diversity in campuses and workplaces by decreasing the entrance criterion for particular groups that are grossly under-represented in proportion to their numbers in the general population. Caste is the most frequently used criterion to identify under-represented groups. The Indian government's prolonged attempt to identify the castes that are illegible for positive discrimination has led to the ramification of a multiplicity of castes and has only reinforced the caste system.

The caste distinctiveness has become a topic of political, social and legal analysis. Communities who get listed as being permitted to benefit under positive discrimination are not removed from this list even if their social and political conditions improve. In many cases the legal system is involved in deciding if a certain person is entitled to positive discrimination. Notwithstanding these positive discrimination policies, most of the communities who were previously low in the caste hierarchy remain low in the social order even

58 The Scheduled Castes and Scheduled Tribes (Prevention of Atrocities) Act of 1989.

59 Art 330 of the IC.

60 Art 332 of the IC.

61 See art 15(4); 164 and 340 of the IC.

62 CERD Reports of India Concluding Observations of Caste 17 September 1996 par 7. 
today. Further, the communities which were high in the social ranking remain high in the social ranking even today. ${ }^{63}$

The reservation system in India seems to be a drastic measure taken to achieve the goal of equality. It is believed that reservations in favour of distinct groups help in attaining a diverse student body which promotes an atmosphere of "speculation, experiment and creation - so essential to the quality of higher education". ${ }^{64}$ However, the reality is that there are no set criteria to select persons outside of the backward classes. When a policy like preferential treatment, reservations or affirmative action is adopted, the reservation policies in India will have to be so arranged that they must not materially affect the right of equality of opportunity, if the advancement of the backward communities is be achieved. ${ }^{65}$ Therefore, affirmative action policies must ensure that the preferential relief employed to correct a particular situation is the least drastic means of remedying discrimination. ${ }^{66}$

Looking at India's system of achieving equality through its use of quotas and reservations, some cautionary lessons are advised. For example, affirmative action is now over fifty years old and each year that equality is not achieved, affirmative action is extended. The government in countries that implement affirmative action must have reasonable goals within set timeframes to achieve the elimination of discrimination. Measures put into place must be monitored, and those that do not achieve their stated goals from must be abandoned. The quota system is not a good system, and merely causes more resentment amongst the non-beneficiary groups. Further, there is ongoing pressure to increase the number of beneficiaries by adding more categories. This creates the risk that affirmative action will be used first and foremost to mobilise voting blocks, and will create hopelessness and antipathy among members of the

63 Aharon 2005 adaniel.tripod.com/modernindia.htm.

64 University of California Regents v Allen Bakke (1978) 438 US 265 at 312.

65 Anand (n 16) 31.

66 See, eg, MR Balaji v State of Mysore (1963) AIR 645 (SC); Amlendu Kumar v State (1980) AIR 1 (Pat) at 7. 
younger age group who feel that their opportunities are limited by their nonOBC status. ${ }^{67}$

What is certain is that affirmative action programmes are the measures to utilise to eliminate the present and continuing effects of past discrimination and to lift the limitations in access to equal opportunities, which limitations have impeded the access of various classes of people to posts in public administration. Such measures as affirmative action or reservations are implemented to remedy the ongoing ill effects of previous inequalities stemming from discriminatory practices against various classes of people, which have resulted in their social, educational and economic backwardness. ${ }^{68}$ The policy also addresses the ongoing discrimination caused by persistent societal discrimination and attacks the continuation of such injustices. ${ }^{69}$ This is the axis on which affirmative action revolves. For equality to be achieved, affirmative action is required. However such affirmative action must be carried out in a constitutionally valid manner.

67 Cunningham (n 44).

68 Justice PB Sawant in Indra Sawhney v Union of India (1993) AIR 477 (SC) at par 23.

69 Singh Affirmative Action Programme. 


\section{Bibliography}

Anand Equality

Anand CL Equality Justice and Reverse Discrimination (Mittal Publications Dheli 1987)

Andrews 1992 SAIPA

Andrews Y "Affirmative Action: A Suspected Equaliser?" 1992 (27) SAIPA:

Journal of Public Administration 34-43

Bhandari Basic Structure

Bhandari MK Basic Structure of the Indian Constitution: A critical reconsideration (Deep \& Deep New Delhi 1993)

Brounaugh "Authority, Equality, Adjudication, Privacy"

Brounaugh R (ed) "Authority, Equality, Adjudication, Privacy" in

Philosophical Law Volume II (Greenwood Press London 1978)

Buhler "The Sacred Laws of the Aryans"

Buhler G "The Sacred Laws of the Aryans as taught in the Schools of Apastamba, Gautama, Vasishta and Baudhayana" in Müller M (ed) The

Sacred Books of the East Volume II (Müller 1879)

Buhler "Manu"

Buhler G "Manu: The Laws of Manu" in Sacred Books of the East Volume 25 (translated) (Dover New York 1969)

CERD Reports of India Concluding Observations of Caste 17 September 1996 Committee on the Elimination of Racial Discrimination Reports of India Concluding Observations of Caste 17 September 1996 HRW

CERD/C/304/Add13 (September 1996) E/CN,4/Sub2/2001/16

Cunningham 1997 Mich LR

Cunningham CD "Race, Class Caste? Rethinking Affirmative Action"1997

(1) Michigan Law Review 1296-1310 


\section{Doniger Laws of Manu}

Doniger W (translated by Smith KB) The Laws of Manu (Penguin Books London 1991)

Fischer 1996 People Dynamics

Fischer S "Affirming Equal Opportunities For White Males" 1996 (14)

People Dynamics 30-34

Galanter Competing Inequalities

Galanter M Competing Inequalities: Law and the Backward Classes In India (University of California Press California 1984)

Ghurye Features of the Caste System

Ghurye GS Features of the Caste System in Caste and Race in India (Popular Prakashan Bombay 1969)

Ginsburg 2000 Brookings Review

Ginsburg RB "Affirmative Action as an International Human Rights

Dialogue" 2000 (18) Brookings Review 3

Hodges We Want Jobs

Hodges G (ed) We Want Jobs: A History of Affirmative Action (Garland New York 1997)

Kroeber "Caste"

Kroeber AL "Caste" in Seligman ERA (ed) Encyclopaedia of the Social

Sciences Volume 3 (Macmillan New York 1930)

Lamb India: World in Transition

Lamb B India: World in Transition (Praeger New York 1970)

Mitchell 1993 Productivity SA

Mitchell G "Much Affirmative Talk (and little action)" 1993 (19) Productivity

SA 28-30

Ryan and Evans 1984 The Commonwealth Government Canberra

Ryan S and Evans G "Affirmative Action for Women" 1984 (1) The

Commonwealth Government Canberra 15-16 
Sachs A "Affirmative Action"

Sachs A "Affirmative Action and Good Government: A fresh look at constitutional mechanisms for re-distribution in South Africa" Alistair

Berkeley Memorial Lecture 14-15 November 1991 (Cape Town 1992)

Searle-Chatterjee and Sharma Contextualising Caste

Searle-Chatterjee M and Sharma U (eds) Contextualising Caste: Post

Dumontian Approaches (Blackwell Oxford 1994)

Seenarine "Dalit Women"

Seenarine M "Dalit Women: Victims or Beneficiaries of Affirmative Action

Policies in India: A Case Study" (Paper presented at a brown bag lecture held at the Southern Asian Institute, Columbia University 10 April 1996)

Sharma and Reddy Reservation Policy in India

Sharma BAV and Reddy KM (eds) Reservation Policy in India (Light and

Life New Delhi 1982)

Singh Affirmative Action Programme

Singh A Affirmative Action Programme: A Comparative Study of India and USA (2002-2003) LLM paper European Academy of Legal Theory Brussels

Tummala 1999 Public Administration Review

Tummala K "Policy of Preference: Lessons from India, the United States and South Africa" 1999 (59) Public Administration Review 495-508

Turner Past and Future

Turner R The Past and Future of Affirmative Action - A Guide and Analysis for Human Resource Professionals and Corporate Counsel (Quorum Books New York 1990)

White Paper GN 564 in GG 18800 of 23 April 1998

White Paper Affirmative Action in the Public Service Department of Public Service and Administration (23 March 1998) GN 564 in GG 18800 of 23 April 1998 


\section{Register of legislation}

Constitution of India 1950

Criminal Tribes Act 1924

Protection of Civil Rights Act 1995

Scheduled Castes and Scheduled Tribes (Prevention of Atrocities) Act 1989

\section{Register of cases}

Amlendu Kumar v State (1980) AIR 1 (Pat)

Devadasen v Union of India (1964) AIR 179 (SC)

Indra Sawhney $v$ Union of India (1993) AIR 477 (SC)

Kumar v State (1969) AIR 182 (Raj)

MR Balaji v State of Mysore (1963) AIR 645 (SC)

Padmaraj Samendra v State (1979) AIR 266 (Pat)

Ramachandra v State of Madhya Pradesh (1961) AIR 247 (Madh Pra)

Savitri v KK Bose (1971) AIR 1974 (HP)

Sukhnandan Thakur v State of Bihar (1957) AIR 617 (Pat)

University of California Regents v Allen Bakke (1978) 438 US 265

\section{Register of Internet sources}

Aharon 2005 adaniel.tripod.com/modernindia.htm

Aharon D 2005 Information on India: Caste System in Modern India adaniel.tripod.com/modernindia.htm [date of use 18 May 2008].

Volokh 1996 volokh.com/sasha/quotas.html

Volokh A 'Quotas in India have yet to create Harmony' Los Angeles Daily Journal 5 November 1996 volokh.com/sasha/quotas.html [date of use 21 Feb 2009]

\section{List of abbreviations}

$\begin{array}{ll}\text { art } & \text { article(s) } \\ \text { ch } & \text { chapter(s) } \\ \mathrm{cl} & \text { clause(s) } \\ \text { IC } & \text { Indian Constitution } \\ \text { OBCs } & \text { Other Backward Classes }\end{array}$


par

SCs

STs paragraph(s)

Scheduled Castes

Scheduled Tribes 